\title{
Retinitis pigmentosa in Lafora disease
}

Expanding findings of progressive myoclonic epilepsy

Figure Lafora disease and retinitis pigmentosa
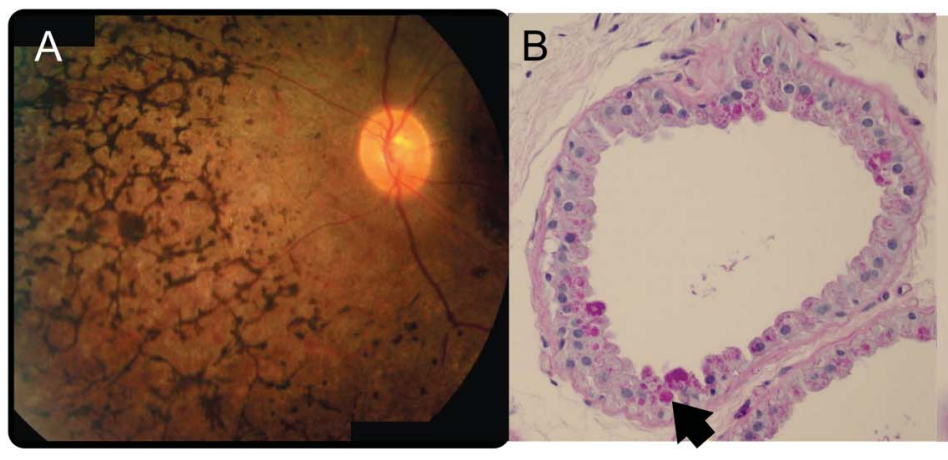

\section{C}
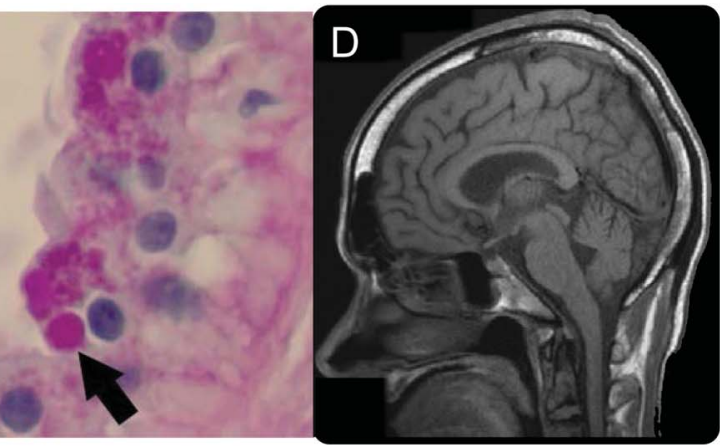

(A) Funduscopic examination discloses retinitis pigmentosa. (B, C) Axillary skin biopsy discloses the pathognomonic periodic acid-Schiff-positive inclusion bodies, the so-called Lafora polyglucosan bodies, in the eccrine ducts of the sebaceous glands (arrow). (D) Sagittal T1-weighted brain MRI shows mild atrophy of the upper portion of cerebellar vermis.

A 21-year-old man presented with a 4-year history of seizures, visual hallucinations, cognitive decline, and gait impairment. Neurologic examination revealed myoclonic jerks, ataxia, and retinitis pigmentosa. Axillary skin biopsy showed Lafora bodies (figure). Lafora disease, the most common progressive myoclonic epilepsy with adolescent onset, is characterized by cognitive decline, visual hallucinations, myoclonus, generalized seizures, and pathognomonic inclusion bodies of polyglucosan found in cells of the skeletal muscle, skin, and brain. ${ }^{1,2}$ Retinitis pigmentosa is a hereditary pigmentary retinopathy commonly present in neurologic disorders such as mitochondrial diseases, abetalipoproteinemia, and Refsum disease ${ }^{3}$; however, it has never been described in Lafora disease.

Wladimir Bocca Vieira de Rezende Pinto, MD, Paulo Victor Sgobbi de Souza, MD,

Jhonatan Rafael Siqueira Pinheiro, MD, Karine Yoshiye Kajizama Okamoto, MD,

Milvia Maria Simões e Silva Enokihara, MD, PhD, Acary Souza Bulle Oliveira, MD, PhD

From the Federal University of São Paulo (UNIFESP), Brazil.

Author contributions: Dr. Pinto: case report project conception, organization, and execution, and writing of the first draft. Dr. Souza: case report project conception, organization, and execution, and writing of the first draft. Dr. Pinheiro: case report project conception, organization, and execution, and writing of the first draft. Dr. Okamoto: case report project conception, organization, and execution, and writing of the first draft. Dr. Enokihara: case report project organization and manuscript review and critique. Dr. Oliveira: case report project organization and manuscript review and critique.

Study funding: No targeted funding reported.

Disclosure: The authors report no disclosures relevant to the manuscript. Go to Neurology.org for full disclosures.

Correspondence to Dr. Pinto: wladimirburpinto@gmail.com

1. de Siqueira LF. Progressive myoclonic epilepsies: review of clinical, molecular and therapeutic aspects. J Neurol 2010;257:16121619.

2. Turnbull J, Girard JM, Lohi H, et al. Early-onset Lafora body disease. Brain 2012;135:2684-2698.

3. Hamel C. Retinitis pigmentosa. Orphanet J Rare Dis 2006;1:40. 


\section{Neurology}

\section{Retinitis pigmentosa in Lafora disease: Expanding findings of progressive myoclonic epilepsy}

Wladimir Bocca Vieira de Rezende Pinto, Paulo Victor Sgobbi de Souza, Jhonatan Rafael

Siqueira Pinheiro, et al.

Neurology 2015;85;1087

DOI 10.1212/WNL.0000000000001957

This information is current as of September 21, 2015

\section{Updated Information \&} Services

References

Citations

Subspecialty Collections

Permissions \& Licensing

Reprints including high resolution figures, can be found at: http://n.neurology.org/content/85/12/1087.full

This article cites 3 articles, 0 of which you can access for free at: http://n.neurology.org/content/85/12/1087.full\#ref-list-1

This article has been cited by 2 HighWire-hosted articles: http://n.neurology.org/content/85/12/1087.full\#\#otherarticles

This article, along with others on similar topics, appears in the following collection(s):

All Epilepsy/Seizures

http://n.neurology.org/cgi/collection/all_epilepsy_seizures

Metabolic disease (inherited)

http://n.neurology.org/cgi/collection/metabolic_disease_inherited Myoclonus; see Movement Disorders/myoclonus

http://n.neurology.org/cgi/collection/myoclonus_see_movement_disord ers-myoclonus

Information about reproducing this article in parts (figures,tables) or in its entirety can be found online at:

http://www.neurology.org/about/about_the_journal\#permissions

Information about ordering reprints can be found online:

http://n.neurology.org/subscribers/advertise

Neurology ${ }^{\circledR}$ is the official journal of the American Academy of Neurology. Published continuously since 1951, it is now a weekly with 48 issues per year. Copyright () 2015 American Academy of Neurology. All rights reserved. Print ISSN: 0028-3878. Online ISSN: 1526-632X.

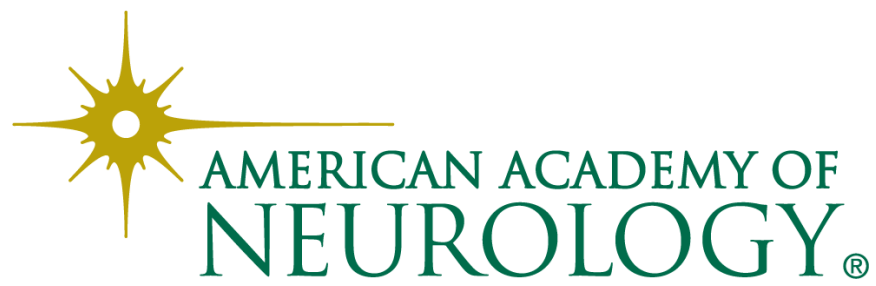

